\title{
A new species of Tyttocharax (Characiformes: Characidae: Stevardiinae) from the Güejar River, Orinoco River Basin, Colombia
}

\author{
César Román-Valencia ${ }^{1}$, Carlos A. García-Alzate ${ }^{1,3}$, Raquel I. Ruiz-C. ${ }^{1}$ and Donald C. \\ Taphorn B. ${ }^{2}$
}

A new Tyttocharax species from the Güejar River system, near the Macarena Mountains in Colombia is described. This is the first record for the genus from the Orinoco basin. The combination of the following characters distinguish Tyttocharax metae from its congeners: presence of bony hooks on the pectoral and caudal-fin rays; bony hooks on the anal-fin rays larger than those on the pelvic-fin rays; pectoral-fin rays i,5-6,i; presence of three unbranched dorsal-fin rays; absence of an adipose fin; four scales rows between the anal-fin origin and the lateral line; and four scale rows between the pelvic-fin and the lateral line. Ecological characteristics of the habitat of the new species are also presented.

Una nueva especie de Tyttocharax se describe para la cuenca del río Güejar, Serranía de La Macarena en Colombia. Tyttocharax metae es un nuevo registro del género para la cuenca del río Orinoco. La combinación de los siguientes caracteres distingue a Tyttocharax metae de sus congéneres: presencia de ganchos óseos en los radios de las aletas pectorales y caudal; ganchos óseos en los radios de la aleta anal de mayor tamaño que los de las aletas pélvicas; radios de las aletas pectorales i,5-6,i; tres radios simples en la aleta dorsal; ausencia de una aleta adiposa; cuatro escamas entre la línea lateral y el origen de la aleta anal, y cuatro escamas entre la línea lateral y las aletas pélvicas. Se incluyen datos ecológicos del hábitat propio del nuevo taxón.

Key words: Geographic distribution, Neotropical fish, Osteology, Scales, Teeth.

\section{Introduction}

The subfamily Stevardiinae sensu Mirande (2010) comprises several characid genera previously listed as incertae sedis in Characidae by Lima et al. (2003), as well as all members of the inseminating characids of the subfamilies Stevardiinae and Glandulocaudinae sensu Weitzman et al. (2005). Among the inseminating stevardiines, Argopleura, Iotabrycon, Scopaeocharax, Tyttocharax, and Xenurobrycon have been proposed to belong to a single tribe by Weitzman \& Fink (1985), the Xenurobryconini. Latter, the tribe was expanded to include Chrysobrycon and Ptychocharax (Weitzman \& Menezes, 1998; Weitzman et al., 1994).

Fishes of the xenurobryconin are sexually dimorphic in a variety of features (Weitzman \& Ortega, 1995; Weitzman \& Menezes, 1998). The great majority of inseminating fishes, including all known Tyttocharax species, exhibit sperm and testis modifications that appear to be adaptations related to this unusual reproductive habit (Burns \& Weitzman, 2005; Pecio et al., 2005).
Weitzman \& Fink (1985) described five synapomorphies that diagnose Tyttocharax: (1) in sexually mature males bony hooks are confined to the posterior six to eight anal-fin rays. These hooks are relatively large and arranged in a vertically elongate cluster. (2) In sexually mature males the posterior three to five proximal anal-fin radials are expanded in to flattened plates that serve as the origin for very robust anal-fin erector and depressor muscles. (3) Mature males and females have about 25 to 40 conical teeth, arranged in four to seven diagonal rows in each premaxilla. (4) Mature males and females have four to eight rows of dentary teeth, all but the innermost diagonal, with a total of 50 to 80 or more teeth on each mandible, and with many of the teeth projecting anteriorly or laterally. (5) The dorso-lateral lamellar process of the angulo-articular bone is absent. Currently, three valid species are recognized in Tyttocharax, all originally described from the Amazon River basin: T. madeirae Fowler, 1913, T. cochui (Ladiges, 1950), and T. tambopatensis Weitzman \& Ortega, 1995.

In this paper we describe a new species of Tyttocharax, providing morphometrics, pigmentation, and osteological

\footnotetext{
${ }^{1}$ Universidad del Quindío, Laboratorio de Ictiología, A. A. 2639, Armenia, Quindío, Colombia. ceroman@uniquindio.edu.co, zutana_1@yahoo.com

${ }^{2} 1822$ N. Charles St., Belleville, IL, 62221 USA. taphorn@gmail.com

33niversidad del Atlántico, Departamento de Biología, Barranquilla, Atlántico, Colombia. caturog@gmail.com
} 
characters for both sexes, to distinguish it from all congeners. It is the first record of the genus from the Orinoco River basin, thus greatly expanding the known range to include the region around the La Macarena mountain range of the Guaviare River drainage in Colombia.

\section{Material and Methods}

Measurements were made with digital calipers to $0.1 \mathrm{~mm}$ precision, and expressed as percentages of standard length (SL) or head length (HL). Measurements and counts were taken on the left side, except when that side was damaged, and recorded following Fink \& Weitzman (1974: 1-2) and Weitzman et al. (1994:48). Counts for the holotype are indicated with an asterisk (*). We performed Principal Component Analysis (PCA) using the Burnaby method to eliminate the influence of size with the PAST program, version 1.81 for Windows (Hammer et al., 2008) to test sexual dimorphism in body shape. Observations of cartilage and bone were made on three cleared and stained specimens (c\&s) prepared following Song \& Parenti (1995). Total vertebral counts were taken from alizarin cleared and stained specimens. These include the vertebrae of the Weberian apparatus as well as the complex caudal ossification, PU1 + U1 with the associated hypural bones and "half vertebrae" all counted as one element. Bone nomenclature follows Weitzman (1962) and Vari (1995). In the lists of paratypes and comparative material, the catalog number is followed by the number of individuals and the range of SL. Examined specimens are from Auburn University Natural History Museum, Auburn, U.S.A. (AUM); Instituto de Investigaciones de Recursos Biológicos "Alexander von Humboldt”, Villa de Leyva, Boyacá, Colombia (IAVH); Instituto de Ciencias Naturales, Museo de Historia Natural-Unidad de Ictiologìa, Universidad Nacional de Colombia, Bogotá, Colombia (ICNMHN); Laboratorio de Ictiología, Departamento de Biología, Universidad del Quindío, Armenia, Colombia (IUQ); Museo Javeriano de Historia Natural-Laboratorio de Ictiología, Departamento de Biología, Pontifica Universidad Javeriana, Bogotá, Colombia (MPUJ); and Museo de Historia Natural, Departamento de Ictiología, Universidad Nacional Mayor de San Marcos, Lima, Perú (MUSM).

\section{Tyttocharax metae, new species Figs. 1-6}

Holotype. IUQ 2581, 15.3 mm SL, adult male, Colombia, Meta, Vista Hermosa near Palestina, río Orinoco basin, río Güejar system, arroyo Pringamosal, tributary of arroyo Blanco $500 \mathrm{~m}$ below Palestina School, 0305'22”N 7349'27’W, 240 m a.s.l., 9 Jan 2009, C. Román-Valencia, C. García-Alzate \& R. Ruiz-C.

Paratypes. All from Colombia: Meta State: La Macarena mountains, río Orinoco basin, río Güejar system unless noted: AUM 50299, 2, 15.7-18.3 mm SL, IUQ 2343, 3, 14.3-18.6 mm SL, Vista Hermosa, La Palestina, arroyo Palestina, 0305’15”N 7349'54”W, 282 m a.s.l., 8 Jul 2008, C. Román-Valencia, C. García-Alzate \& R. RuizC. IUQ 2344, 4, 13.3-14.0 mm SL, IUQ 2345, 3, 13.2-14.5 mm SL,
Vista Hermosa, La Palestina, creek 2 km north of Las Brisas, road to Vista Hermosa, 0303’00”N 7349’05”W, 264 m a.s.l., 10 Jul 2008, C. Román-Valencia, C. García-Alzate \& R. Ruiz-C. MPUJ 6135, 2, 14.1-15.8 mm SL, Vista Hermosa, La Palestina, creek 2 km north of Las Brisas, road to Vista Hermosa, 0303’00”N 7349’05”W, 264 m a.s.l., 10 Jul 2008, C. Román-Valencia, C. García-Alzate \& R. RuizC. IUQ 2346, 1, 11.4 mm SL, Granada, río Ariari system, arroyo Mucuyita 0327’05”N 7347’49”W, 301 m a.s.l., 7 Jul 2008, C. Román-Valencia, C. García-Alzate \& R. Ruiz-C. IUQ 2347, 2, 12.9 14.1 mm SL, IUQ 2493, 1, 18.4 mm SL, collected with the holotype. IUQ 2494, 2, 13.2-14.3 mm SL, Vista Hermosa, Puerto Lucas, arroyo Acacias on road to Vista Hermosa, 0305’24”N 7345’32”W, 240 m a.s.l., 8 Jan 2009, C. Román-Valencia, C. García-Alzate \& R. RuizC. IUQ 2496, 1 c\&s, 12.3 mm SL, Vista Hermosa, Puerto Lucas, arroyo Luciana 100 m north of bridge in Puerto Lucas, 0306'22”N 7346’44”W, 253 m a.s.l., 8 Jul 2008, C. Román-Valencia, C. GarcíaAlzate \& R. Ruiz-C. IUQ 2495, 3 c\&s, 12.4-13.6 mm SL, Vista Hermosa, La Palestina, creek 1 km north of Las Brisas, 0302'55”N 7349’10’W, 278 m a.s.l., 10 Jul 2008, C. Román-Valencia, C. GarcíaAlzate \& R. Ruiz-C. IUQ 2755, 4, 15.4-17.1 mm SL, Vista Hermosa, La Palestina, arroyo Pringamosal, 0305'29”N 7349'47’W, 273 m a.s.l., 9 Nov 2009, M. I. González \& A. M. Barrero.

Diagnosis. Tyttocharax metae can be distinguished from all congeners by having bony hooks on the pectoral and caudalfin rays (vs. absent). Differs from T. madeirae and T. cochui by the absence of adipose fin (vs. adipose fin present), in having larger bony hooks on the anal fin than on the rays of the pelvic fins ( $v s$. bony hooks of the same size on the rays of those fins). Differs from T. cochui in having i,5-6 pectoral-fin rays (vs. i,7). Tyttocharax metae can be distinguished from $T$. tambopatensis by absence of a sexually dimorphic color pattern in life ( $v s$. presence of sexually dimorphic color pattern, males have bright orange abdomens), by the number of scales rows between anal-fin origin and lateral line ( 4 vs. 6 ), by the number of scale rows between pelvic-fin and lateral line (4 vs. 6), by the number of branched pectoral-fin rays (5-6 vs. 7); by the number of unbranched dorsal-fin rays (iii vs. ii) and distance between the dorsal and anal-fin origins (22.3 to 32.2\% SL vs. 38.0-41.0\% SL).

Description. Morphometric and meristic data for holotype and paratypes in Table 1 . Body deepest between verticals through pelvic-fin and dorsal-fin origins in females; deepest between verticals through posterior margin of dorsal-fin base and middle part of anal-fin base in males. Predorsal profile of body generally convex in both sexes. Body profile slightly elevated at dorsal-fin origin then slightly concave from dorsalfin origin to procurrent caudal-fin rays; slightly convex near tips of depressed dorsal-fin rays in males. Origin of dorsal fin nearer caudal-fin base than snout. Dorsal-fin origin at vertical through anal fin in females; anterior to vertical through analfin origin in males. Tips of pelvic-fin rays reach anal-fin origin in both sexes. Ventral profile of body convex from tip of lower jaw to pelvic-fin insertion. Ventral body profile convex along anal-fin base in males, concave in females. Ventral profile of caudal peduncle convex in females, concave in sexually dimorphic males (Figs. 1 and 2). Lower jaw prominent, 
projecting beyond upper jaw. Jaws and lips of mature males moderately thickened with specialized accommodation of prominent premaxillary teeth outside of snout. Lips thin in females. Maxilla extending anteriorly to antero-ventral border of eye in sexually dimorphic males and females.

All teeth conical and distributed over surface of mandibles in an apparently random pattern that makes them difficult to count in traditional rows. Number and distribution of teeth sexually dimorphic, with males having higher number and more prominent teeth (Fig. 3). In males, premaxilla with four to five sets of teeth, each with 18 to 22 conical teeth that extend over its entire surface; fewer teeth in females, restricted to ventral half of premaxilla, with up to three sets of conical teeth, each with a maximum of 15 teeth; only two to three teeth in upper row. Maxilla in males with two to three sets of teeth that overlap dorsally; only one series of larger wellseparated teeth ventrally. Maxilla in females with only one series of non-overlapping teeth positioned dorsally (Fig. 3). Dentary in males with four sets of 25 to 30 unicuspid teeth randomly distributed in front of dentary; reduced to two series laterally where they overlap with maxillary teeth. Females with only two to three sets of the teeth in front reducing to just one series laterally.

Scales cycloid, small. Lateral line complete, perforated scales 31-34 $\left(31^{*}\right.$, mode $\left.=33\right)$. Scale rows between dorsal-fin origin and lateral line five $(n=28)$; scale rows between lateral line and anal-fin origin four $(\mathrm{n}=28)$; scale rows between lateral line and pelvic-fin insertion four $(\mathrm{n}=28)$. Predorsal scales $13-14$, arranged in regular series $\left(13^{*}\right.$, mean $=13.7$, mode $=13)$. Dorsal-fin rays ii,5-7,i (ii,5,i*, $n=28)$; first unbranched ray approximately one-half length of second ray, its tip reaching proximal bifurcation of first branched ray. Analfin rays ii,13-18,i (ii,14,i*; ii,13-14,i in males and ii,14-18,i in females, $n=26$ ). Pectoral-fin rays i,5-6,i (i,5,i*; i,5-6,i in males and females). Pelvic-fin rays i,3-6,i (i,3,i*; i,3-4,i in males and $\mathrm{i}, 3-6, \mathrm{i}$ in females, $\mathrm{n}=26$ ). Pelvic-fin origin anterior to vertical through dorsal-fin origin. Caudal-fin pouch scale of irregular shape with approximately 26-28 radii (Fig. 6). Total number of vertebra 40-41.

Maxilla angular, more pronounced in females in which ventral margin extends anteriorly and teeth cover anterior half of this structure. Supraneurals absent. Five infraorbitals, the first vestigial, infraorbitals two to five in typical position for genera included in Stevardiinae. The third infraorbital not in contact with preopercular sensory canal. Anterior margin of sphenotic extending over fifth infraorbital. Supraoccipital spine short, not reaching anterior margin of neural complex. Orbitosphenoid bone with an extension in anterior ventral region with bands of cartilage in anterior and posterior margins. Rhinosphenoid bone square, contacting orbitosphenoid and parasphenoids by bands of cartilage. Parasphenoid not divided, joined to ventral vomer surface by cartilage; posterior end of parasphenoid in contact with prootic and basioccipital by band of cartilage.

Dorsal margin of metapterygoid wide with a crest, foramen present in medial posterior region, with band of cartilage between it and quadrate. Ectopterygoid long and narrow, not in contact with quadrate. Mesopterygoid with entire dorsal margin in contact with ventral region of parasphenoid, band of cartilage over entire antero-ventral margin that connects to ectopterygoid.

Table 1. Morphometric data of holotype (male) and paratypes (A, adult males including the holotype and B, adult females and juveniles) of Tyttocharax metae. Values in parentheses $=$ mean. $\mathrm{SD}=$ Standard deviation.

\begin{tabular}{lccccc}
\hline \multirow{2}{*}{\multicolumn{1}{c}{ Morphometric }} & \multicolumn{4}{c}{$\mathrm{A}$} & $\mathrm{B}$ \\
\cline { 2 - 6 } & Holotype & $\mathrm{n}=12$ & $\mathrm{SD}$ & $\mathrm{n}=16$ & $\mathrm{SD}$ \\
\hline Standard length (mm) & 15.3 & $12.6-15.8(13.9)$ & 1.3 & $12.6-15.7(14.0)$ & 1.0 \\
Total length (mm) & 19.7 & $16.8-20.7(18.0)$ & 1.6 & $16.2-20.2(18.1)$ & 1.3 \\
\multicolumn{4}{c}{ Percentages of standard length } \\
Body depth & 26.6 & $20.2-30.1(25.7)$ & 3.2 & $20.8-27.1(24.4)$ & 2.5 \\
Snout-dorsal fin distance & 64.0 & $58.7-67.0(62.3)$ & 1.5 & $55.5-63.3(60.6)$ & 2.7 \\
Snout-pectoral fin distance & 29.9 & $21.1-33.0(27.1)$ & 2.4 & $23.2-29.9(26.7)$ & 2.7 \\
Snout-pelvic fin distance & 42.6 & $39.3-48.2(43.2)$ & 2.7 & $41.0-50.0(46.5)$ & 2.9 \\
Dorsal-pectoral fin distance & 46.4 & $40.6-46.6(42.2)$ & 2.0 & $36.5-45.4(41.8)$ & 3.0 \\
Snout-anal fin distance & 66.6 & $57.9-66.7(63.3)$ & 2.8 & $60.3-64.4(62.8)$ & 2.9 \\
Dorsal fin-hypural distance & 41.5 & $41.1-47.8(42.3)$ & 3.2 & $39.3-44.7(41.3)$ & 3.1 \\
Dorsal-anal fin distance & 26.4 & $22.3-32.2(27.2)$ & 1.9 & $22.1-29.3(23.8)$ & 1.2 \\
Dorsal-fin length & 21.2 & $17.4-26.8(21.1)$ & 1.8 & $15.8-24.3(19.7)$ & 1.7 \\
Pectoral-fin length & 23.0 & $16.0-25.3(20.1)$ & 2.0 & $16.3-22.5(20.0)$ & 2.7 \\
Pelvic-fin length & 23.1 & $18.8-32.6(24.6)$ & 3.1 & $10.9-22.1(17.1)$ & 2.8 \\
Anal-fin length & 19.4 & $14.7-24.7(19.0)$ & 2.8 & $13.3-18.1(15.8)$ & 2.8 \\
Caudal peduncle depth & 12.2 & $11.3-15.5(12.7)$ & 1.7 & $7.1-12.1(10.1)$ & 3.0 \\
Caudal peduncle length & 5.8 & $5.7-10.6(7.8)$ & 1.5 & $7.5-12.7(9.9)$ & 1.8 \\
Head length & 29.3 & $22.5-29.4(26.3)$ & 2.2 & $21.6-26.4(24.1)$ & 2.6 \\
& Percentages of head length & & & \\
Snout length & 32.2 & $19.0-38.4(27.6)$ & 4.4 & $22.7-35.6(29.7)$ & 4.2 \\
Orbital diameter & 37.9 & $37.7-49.3(42.7)$ & 4.4 & $41.4-54.4(47.8)$ & 5.3 \\
Postorbital distance & 35.8 & $22.1-35.8(29.8)$ & 4.0 & $31.1-39.9(35.5)$ & 4.9 \\
Maxilla length & 16.6 & $15.6-34.7(21.7)$ & 4.6 & $15.6-28.2(21.8)$ & 4.3 \\
Interorbital distance & 33.9 & $33.4-44.4(38.4)$ & 4.6 & $35.7-47.1(42.5)$ & 4.9 \\
Upper jaw length & 23.1 & $21.4-33.7(28.2)$ & 3.0 & $26.0-32.8(29.6)$ & 3.7 \\
\hline
\end{tabular}




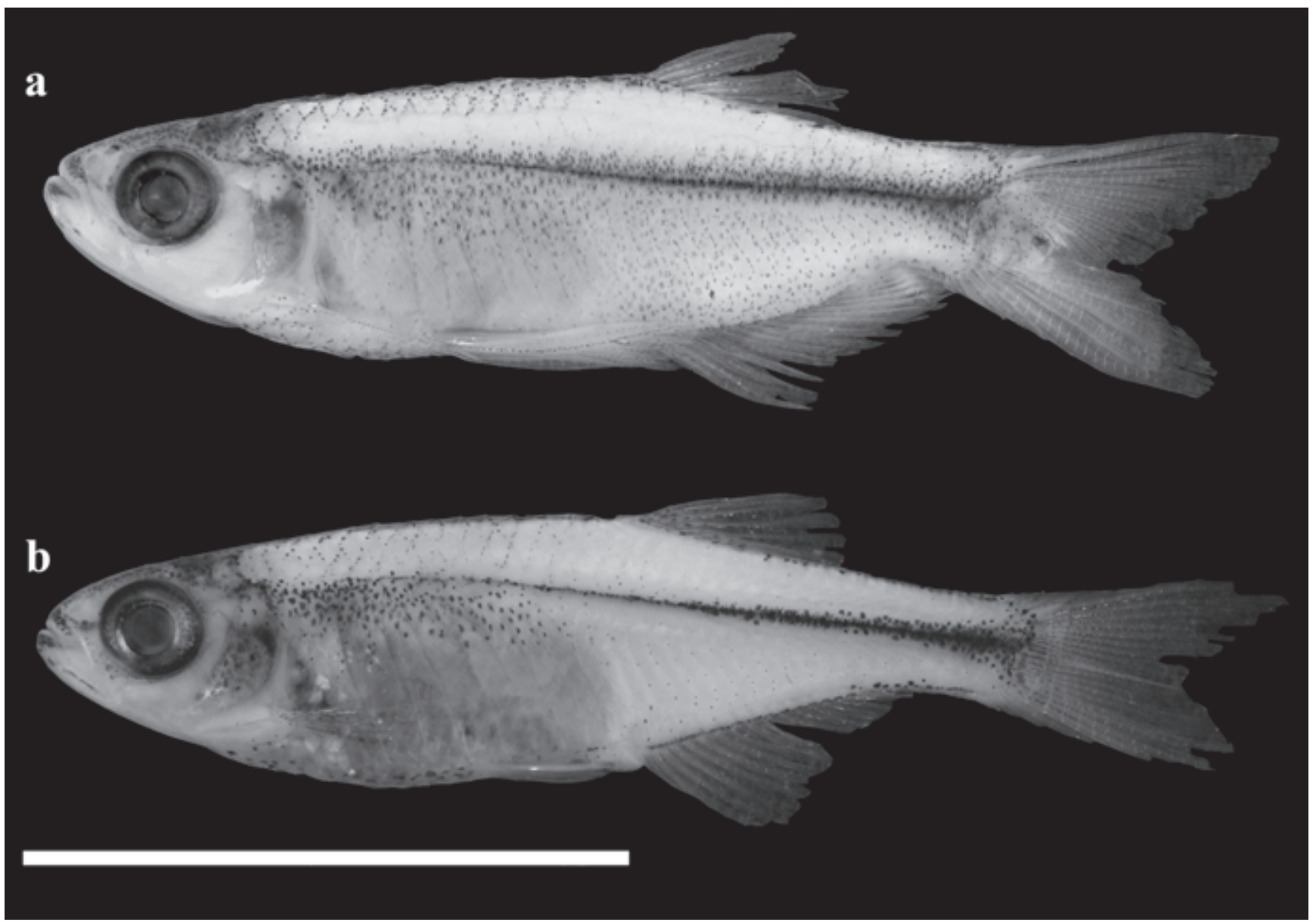

Fig. 1. Tyttocharax metae, Colombia, Meta. a) holotype, IUQ 2581, adult male, 15.3 mm SL; b) paratype, IUQ 2343; adult female, $15.5 \mathrm{~mm}$ SL. Scale bar $=1 \mathrm{~cm}$.

Nasal bone present. Basihyal cartilaginous not divided. Pharyngeal curved, an elongated plate, with thick cartilage at dorsal and ventral ends. Sixteen gill rakers on first branchial arch; 4-5 gill rakers on ceratobranchial and 11-12 gill rakers on epibranchial. Pectoral girdle with pointed dorsal process on cleithrum. Cleithrum elongated with straight posterior border; located under ventral edge of operculum. Anterior border of scapula straight. Postcleithrum 1 and 2 absent, postcleithrum 3 elongated and curved covering more than half of cleithrum. Proximal pterygiophore rays of dorsal fin inserted between neural spines 10 and $16 ; 17^{\text {th }}$ proximal pterygiophore of anal fin inserted between hemal spines 11 and 12.

Color in alcohol. See Figs. 1 and 2 for pigment patterns in preserved males and females. Body light yellow, dark brown on dorsum with dark spot at base of caudal peduncle. Sides of body with dark stripe that starts posterior to operculum and extends to caudal spot and widens at level of vertical through posterior tip of ventral-fin rays. Posterior margins of scales located on upper sides anterior to dorsal fin dark. Pectoral, pelvic and anal fins hyaline. Dorsal area of head dark. Humeral spot visible.
Color in life. Dorsum of body, head and post ventral area greenish yellow, with an evident absence of dark pigment. Sides of body with blue stripe, caused by presence of iridophores that generate an iridescent bluish aspect known as Rayleigh scattering. The iridophores are limited on sides

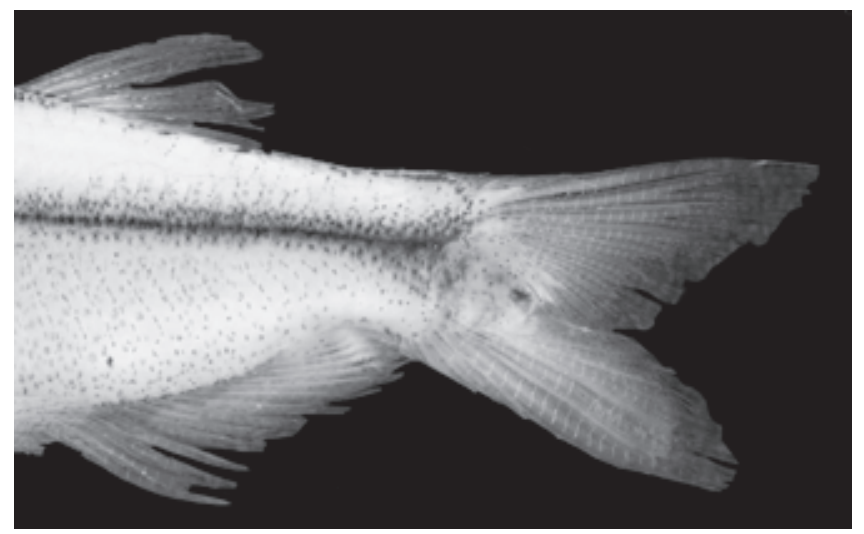

Fig. 2. Tyttocharax metae, paratype, IUQ 2343, adult male, $18.4 \mathrm{~mm}$ SL. Caudal peduncle and fin, left lateral view. 

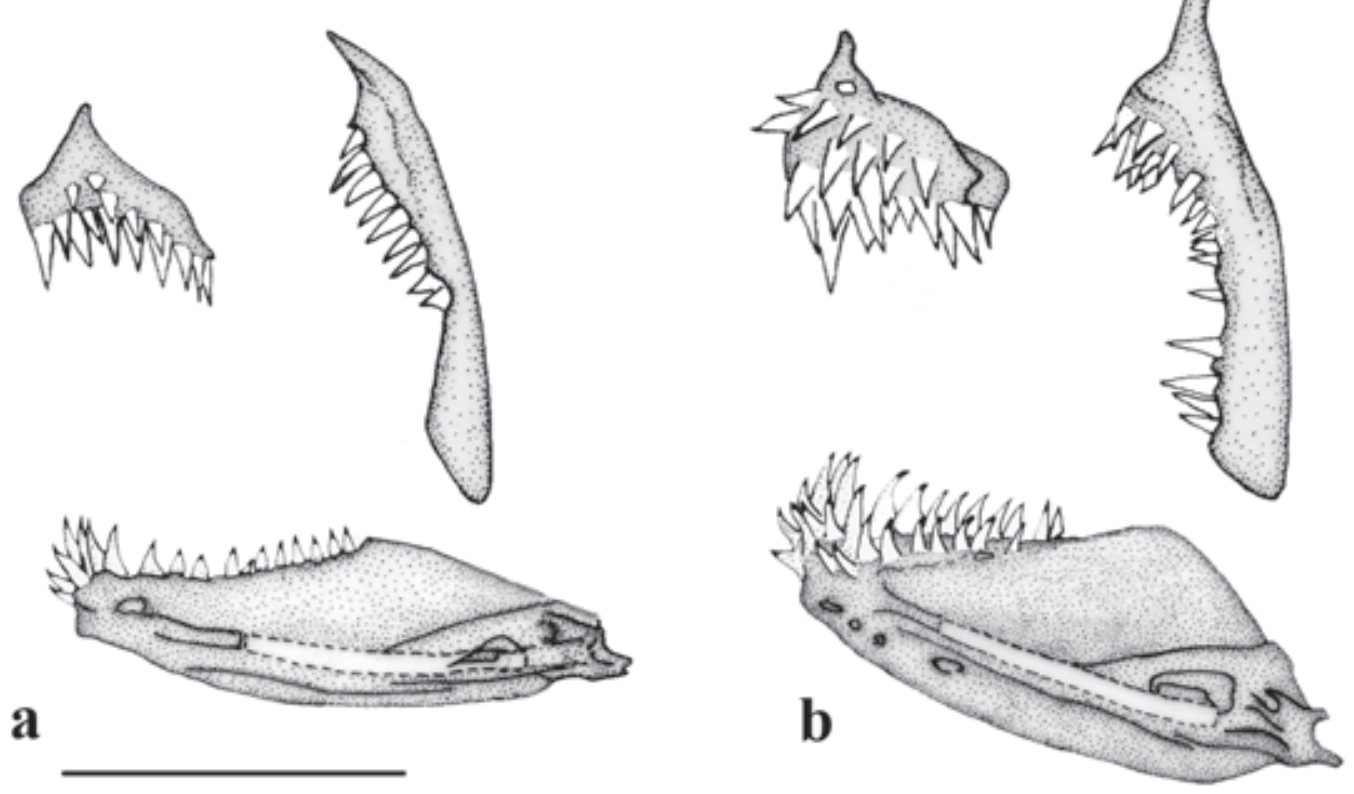

Fig. 3. Tyttocharax metae, paratypes, IUQ 2493, $18.4 \mathrm{~mm}$ SL. Maxilla, premaxilla and dentary, left lateral view. a) female; b) male; scale bar $=1 \mathrm{~mm}$.

to just dorsal margin of coelomic cavity. From there they extend posteriorly to the caudal peduncle. Lateral surface of coelomic cavity covered with leucophores that color this part of fish white. Bases of middle caudal-fin rays covered with narrow band of melanophores, more concentrated on dorsal lobe of caudal fin, and forming caudal spot. Posterior border of opercle covered by shiny blue iridophores. Humeral spot horizontally elongated and formed by disperse melanophores in area along dorsal margin of coelomic cavity, overlaing iridophores. Anal-fin rays with dispersed melanophores along their bases. All the fins hyaline. Color pattern identical in males and females.

Sexual dimorphism. Neither the principal component analysis among species of Tyttocharax nor regressions comparing males and females produced significant results. In males, teeth are found along entire length of anterior margin of maxilla, which is less sharply pointed on its ventral tip than in females. In both sexes maxillary teeth diminish gradually in size (Fig. 3). Posterior pterygiophores (last two or three including terminal piece) of anal fin in males of Tyttocharax metae are swollen, but in females are vestigial. Five or six penultimate anal-fin rays each have a pair of bony hooks (Fig. 3) present at distal extremity. Fin-ray segment dorsal to one with hook thickened in last rays with hooks (Fig. 4).

Pelvic fin of T. metae with i,3-6,i rays as in T. tambopatensis, but distribution of hooks is different: four hooks are present on simple ray and last branched ray, with one pair at terminus of each segment on their distal margins; five hooks are found on first and penultimate branched rays (Fig. 5). Three or four bony hooks are present on middle portion of caudal-fin rays. Principal caudal-fin ray count 10/7. Eleventh principal caudal-fin ray (as identified in females) is transformed in males into an accessory structure coupled to caudal scale (Fig. 6). Anterior anal-fin lobe larger in males (18.9\% SL) than in females (15.1\% SL).

Distribution. This species is known from the río Güejar system in Meta State, La Macarena Mountains, Orinoco basin, Colombia (Fig. 7).

Etymology. The specific epithet refers to the Meta State, in eastern Colombia, where the new species was collected.

Ecological notes. This new species was captured in streams characterized by relatively rapid water current, running

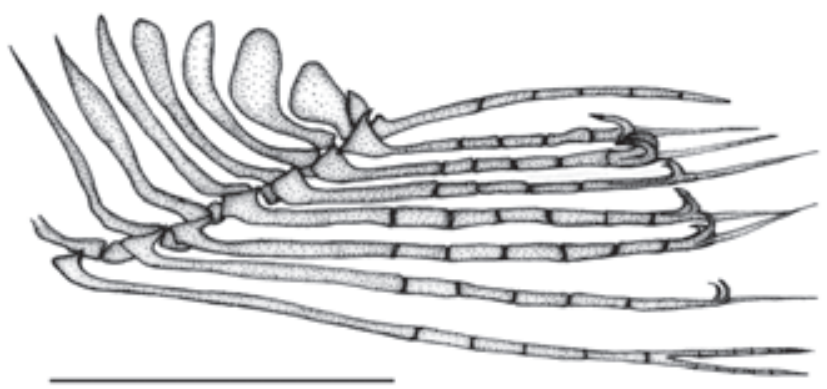

Fig. 4. Tyttocharax metae, paratype, IUQ 2343, adult male, $18.4 \mathrm{~mm}$ SL. Posterior eight anal-fin rays and supporting pterygiophores left lateral view. Posterior ray split to its base with anterior half bearing bony hooks. Scale bar $=1 \mathrm{~mm}$. 


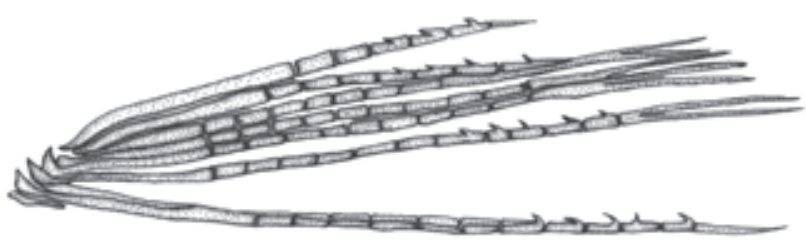

Fig. 5. Tyttocharax metae, paratype, IUQ 2343, adult male, $18.4 \mathrm{~mm}$ SL. Pelvic-fin rays illustrating distribution of pelvicfin hooks, left side, ventro-medial view. Scale bar $=1 \mathrm{~mm}$.

over rocky and sandy bottoms at altitudes between 264$282 \mathrm{~m}$ a.s.l. Water depth was from 0.5 to $3 \mathrm{~m}$. and stream width between 1 to $4 \mathrm{~m}$. Riparian vegetation was grass and trees. The transparency of the tea colored water was usually high, dissolved oxygen was also relatively high (5.7-7.1 $\mathrm{mg} / \mathrm{l}), \mathrm{pH}$ was usually around neutral (7.1-7.6). Fish species collected with T. metae are Aphyocharax alburnus, Astyanax sp., Bujurquina sp., Bryconamericus cismontanus, Charax metae, Creagrutus calai, Farlowella vittata, Hemigrammus marginatus, Hoplias malabaricus, Hyphessobrycon metae, Moenkhausia lepidura group, and Pyrrhulina brevis.

Remarks. The shape of the last anal-fin pterygiophore is reported to have an undulated margin in T. madeirae (Weitzman \& Fink, 1985) and an obvious notch in $T$. tambopatensis (Weitzman \& Ortega, 1995). In T. metae the margin of the last anal-fin pterygiophore is concave and halfmoon shaped.

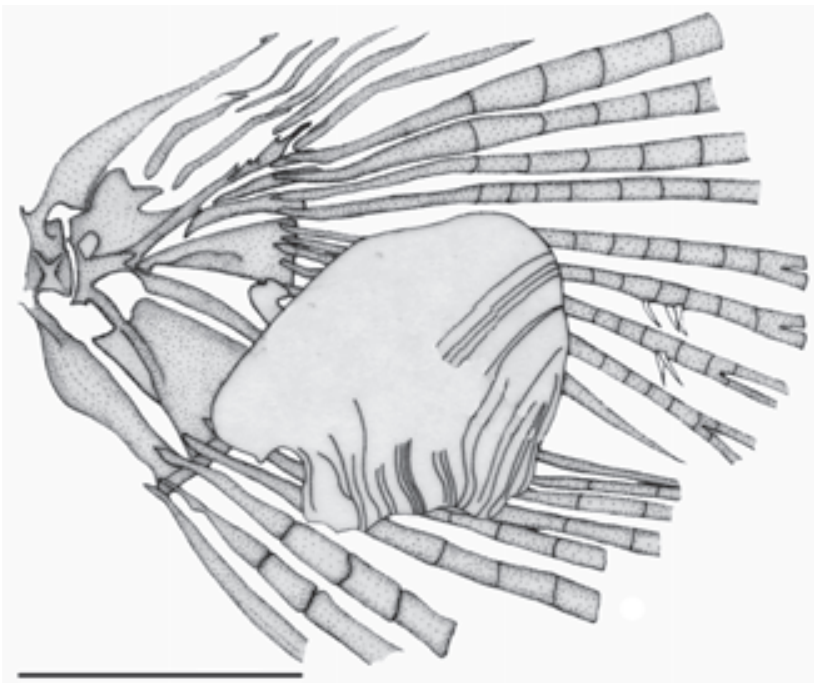

Fig. 6. Tyttocharax metae, paratype, IUQ 2343, adult male, $18.4 \mathrm{~mm}$ SL. Caudal skeleton view, left lateral view, pouch scale. Scale bar $=1 \mathrm{~mm}$.

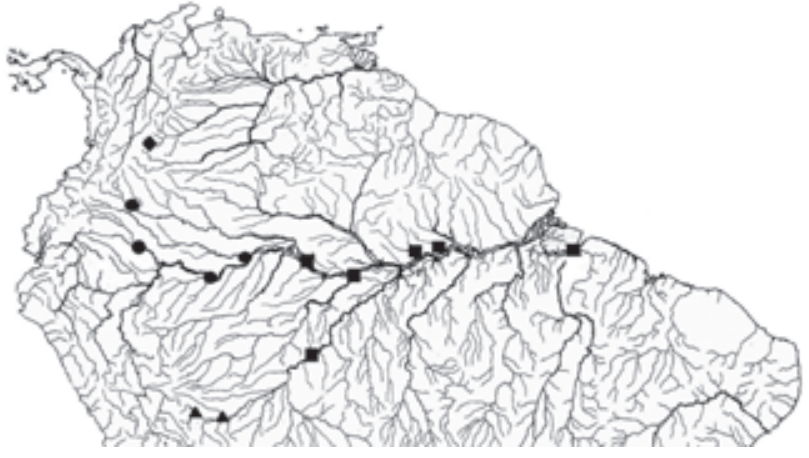

Fig. 7. Distribution map for species of Tyttocharax: T. cochui $(\bullet)$, T. madeirae $(\boldsymbol{\square})$, T. tambopatensis $(\boldsymbol{\Delta})$ and T. metae $(\bullet)$. Modified from Weitzman \& Ortega (1995).

The distal extremity of principal caudal-fin ray 11 is leaf-shaped in T. metae with a straight but inclined dorsal margin and arched, protruding ventral margin vs. shaped as an elongate, thickened tubercle in T. madeirae. Three hooks on principal caudal-fin ray 7 and two on principal caudal-fin ray 8 . The uroneural is subdivided in T. metae vs. uroneural continuous in T. madeirae.

Four of the five synapomorphies described for Tyttocharax (Weitzman \& Fink, 1985) are present in T. metae, except for the smaller number of dentary teeth in T. metae (fewer than 50 teeth in each jaw, Fig. 3, instead of a total of 50 to 80 or more teeth on each mandible). It is possible that this difference results from the difference in size of the fishes studied by us and by Weitzman \& Fink (1985).

Comparative material. Tyttocharax madeirae: all from Colombia, Amazonas, Amazon Basin: ICNMHN 6325, 33, 10.4-13.9 mm SL, km 95 Letícia-Tarapacá road, arroyo La Arenosa; ICNMHN 10329, 6, 14.9-16.6 mm SL, Letícia, tributary of Amazon River, km 6.5, Tarapacá road, arroyo Tacana; ICNMHN 10045, 2, 15.8-17.8 mm SL, Letícia, tributary of Amazon River, arroyo Tacana; IAvH 8301, 13, 12.9-17.7 mm SL, Letícia, Matamatá Creek, 0348’23'’S 70¹5’59’'W; IAvH 8302, 4 (c\&s), 16.3-20.3 mm SL, Letícia, tributary of Amazon River; IAvH 11171, 5, 13.0-18.4 mm SL; Letícia, arroyo Sufragio, El Zafire biological station; IAvH 11170, 23, 11.6-15.9 mm SL, Letícia, arroyo Sufragio at El Zafire biological station; IAvH 8304, 127, 15.1-20.9 mm SL, Letícia, IAvH 8304, 7 (c\&s), 134, 15.4-19.8 mm SL, Letícia, río Purité, 0341'35’'S 70¹2’26”W; IAvH 11168 , 5, 16.0-20.2 mm SL, Letícia, arroyo Gravilla at El Zafire biological station; IAvH 11169, 48, 11.6-20.3 mm SL, Letícia, IAvH 11169 , 8 (c\&s), 15.9-18.5 mm SL, Letícia, arroyo Sufragio at El Zafire biological station. MPUJ 3461, 4, 16.6-20.0 mm SL, Letícia. Tyttocharax tambopatensis: MUSM 5087, 7 of 13 paratypes, 11.6-14.3 mm SL, Peru, Madre de Dios, Tambopata, Tambopata Reserve, río Tambopata, creek water stream at $\mathrm{km} \mathrm{3,} \mathrm{Tapir} \mathrm{trail.}$

\section{Acknowledgements}

We thank the University of Quindío, Vicerrectoria de Investigaciones to C.R-V and C.A.G which financed this study. We also thank the following persons and museums for loans 
of material under their care: Jaime Aguirre C. (ICNMHN), Juan D. Bogotá (IAvH), Saul Prada-P. (MPUJ) and Hernán Ortega (MUSM). We are most grateful to the Juan B. Barrero (Centro Docente "La Palestina", Vista Hermosa, Meta) and the Marin family (Gonzaga, Ordanet and Javier) for their help and generous hospitality in La Macarena. We also thank Peter Bartsch and Luiz R. Malabarba for the corrections and suggestions to improve the paper. Alejandro Escobar Ruiz prepared figures 1 and 2 .

\section{Literature Cited}

Burns, J. R. \& S. H. Weitzman. 2005. Insemination in ostariophysan fishes, p. 107-134. In: Viviparous Fishes. H. J. Grier \& M. C. Uribe (eds.). New Life Publications, Homestead, Florida.

Fink, W. L. \& S. H. Weitzman. 1974. The so-called Cheirodontin fishes of Central America with descriptions of two new species (Pisces: Characidae). Smithsonian Contributions to Zoology, 172: $1-45$

Fowler, W. H. 1913. Fishes from the Madeira River, Brazil. Proceedings of the Academy of Natural Sciences of Philadelphia, 65: 517-579.

Hammer, Ø., D. A. T. Harper \& P. D. Ryan. 2008. PASTPaleontological Statistics, version 1.81: 1-88.

Ladiges, W. 1950. Microbrycon cochui spec. nov. eine neu Art der südamerikanischen Glandulocaudinae. Zoologischer Anzeiger, 145: 305-309.

Lima, F. C. T., L. R. Malabarba, P. A. Buckup, J. F. P. da Silva, R. P. Vari, A. Harold, R. Benine, O. T. Oyakawa, C. S. Pavanelli, N. A. Menezes, C. A. S. Lucena, M. C. S. L. Malabarba, Z. M. S. Lucena, R. E. Reis, F. Langeani, L. Casatti, V. A. Bertaco, C. Moreira \& P. H. F. Lucinda. 2003. Genera incertae sedis in Characidae. Pp. 106-169. In: Reis, R. E., S. O. Kullander \& C. Ferraris Jr. Check list of the freshwater fishes of South and Central America. Porto Alegre, EDIPUCRS, 729p.

Mirande, M. 2010. Phylogeny of the family Characidae (Teleostei: Characiformes): from characters to taxonomy. Neotropical Ichthyology, 8: 385-568.

Pecio, A., J. R. Burns \& S. H. Weitzman. 2005. Sperm and spermatozeugma ultrastructure in the inseminating species Tyttocharax cochui, T. tambopatensis, and Scopaeocharax rhinodus (Pisces: Teleostei: Characidae: Glandulocaudinae: Xenurobryconini). Journal of Morphology, 263: 216-226.

Song, J. \& L. R. Parenti. 1995. Clearing and staining whole fish specimens for simultaneous demonstration of bone, cartilage and nerves. Copeia, 1995: 114-118.

Vari, R. P. 1995. The Neotropical fish family Ctenoluciidae (Teleostei: Ostariophysi: Characiformes): supra and intrafamilial phylogenetic relationships, with a revisionary study. Smithsonian Contributions to Zoology, 564: 1-96.

Weitzman, S. H. 1962. The osteology of Brycon meeki, a generalized characid fish, with an osteological definition of the family. Stanford Ichthyological Bulletin, 8: 1-77.

Weitzman, S. H. \& S. V. Fink. 1985. Xenurobryconin phylogeny and putative pheromone pumps in Glandulocaudine fishes (Teleostei: Characidae). Smithsonian Contributions to Zoology, 421: 1-118.

Weitzman, S. H., S. V. Fink, A. Machado-Allison \& R. Royero L. 1994. A new genus and species of Glandulocaudinae (Teleostei: Characidae) from Southern Venezuela. Ichthyological Exploration of Freshwaters, 5: 45-64.
Weitzman, S. H. \& N. A. Menezes. 1998. Relationships of the tribes and genera of the Glandulocaudinae (Ostariophysi: Characiformes: Characidae) with a description of a new genus, Chrysobrycon). Pp. 171-192. In: L. R. Malabarba, R. E. Reis, R. P. Vari, Z. M. Lucena \& C. A. Lucena (Eds.), Phylogeny and Classification of Neotropical Fishes, Porto Alegre, Edipucrs, 603p.

Weitzman, S. H., N. A. Menezes, H.-G. Evers \& J. R. Burns. 2005. Putative relationships among inseminating and externally fertilizing characids, with a description of a new genus and species of Brazilian inseminating fish bearing an anal-fin gland in males (Characiformes: Characidae). Neotropical Ichthyology, 3: 329-360.

Weitzman, S. H. \& H. Ortega. 1995. A new species to Tyttocharax (Teleostei: Characidae: Glandulocaudinae: Xenurobryconini) from the Madre de Dios basin of Peru. Ichthyological Exploration of Freshwaters, 6: 129-148.

Weitzman, S. H. \& L. Palmer. 1997. A new species of Hyphessobrycon (Teleostei: Characidae) from the Neblina region of Venezuela and Brazil, with comments on the putative 'rosy tetra clade'. Ichthyological Exploration of Freshwaters, 7: 209-242.

Submitted July 13, 2010

Ressubmitted April 7, 2011

Accepted June 15, 2012

Published September 28, 2012 